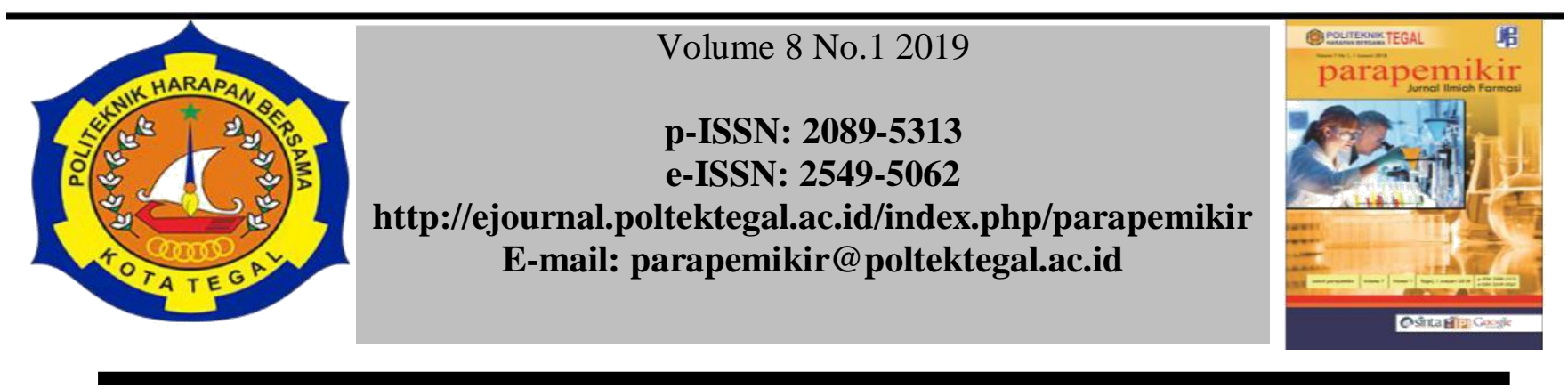

\title{
EVALUASI PELAKSANAAN PELAYANAN KEFARMASIAN DI APOTEK WILAYAH KOTA TEGAL TAHUN 2018 (BERDASARKAN PERMENKES NO 35. TAHUN 2014)
}

\author{
Sari Prabandari ${ }^{1}$, Anggy Rima Putri ${ }^{2}$ \\ 12 Politeknik Harapan Bersama \\ Email : sariprabandari.sp@gmail.com
}

\begin{tabular}{|c|c|}
\hline Article Info & Abstrak \\
\hline Article history: & \multirow{11}{*}{$\begin{array}{l}\text { Pemerintah mengeluarkan Peraturan Menteri Kesehatan No. } 35 \text { tahun } 2014 \text { tentang } \\
\text { Standar Farmasi di Farmasi untuk dijadikan pedoman bagi praktik apoteker dalam } \\
\text { melaksanakan tugas profesional untuk melindungi masyarakat dari Layanan. Tujuan } \\
\text { dari penelitian ini adalah untuk mengetahui evaluasi penerapan standar pelayanan } \\
\text { kefarmasian di Apotek Daerah Kota Tegal pada tahun 2018. Penelitian ini merupakan } \\
\text { penelitian analisis kuantitatif deskriptif. Sumber data penelitian utama dan alat dalam } \\
\text { penelitian ini adalah lembar kuesioner. Hasil Penelitian dari Aspek Manajemen } \\
\text { Sediaan Farmasi dan Perbekalan Kesehatan Farmasi di Kota Tegal telah melakukan } \\
\text { pengelolaan Sediaan Farmasi dengan Kategori Baik, serta Aspek Manajemen Sumber } \\
\text { Daya Farmasi dalam hal keberadaan Apoteker dan Tenaga Medis, tetapi ada sedikit } \\
\text { atau tidak ada apoteker di Apotek. Aspek fasilitas dan infrastruktur dalam menyediakan } \\
\text { ruang tertutup untuk konseling hanya dapat dikatakan mencukupi. Aspek Layanan } \\
\text { Farmasi Klinis dikatakan kurang untuk memantau terapi obat, memantau efek samping } \\
\text { obat, dan perawatan di rumah1. Dari aspek evaluasi kualitas layanan, catatan rekam } \\
\text { medis dikatakan kurang. Sedangkan kualitas layanan klinis juga dikatakan baik untuk } \\
\text { perhatian terhadap alergi, pemeriksaan obat-obatan farmasi, dan pemeriksaan } \\
\text { ketersediaan obat, tetapi kurangnya perhatian pada pengobatan ganda dan } \\
\text { kontraindikasi. Serta dalam dimensi waktu tunggu, layanan obat dikatakan cukup. }\end{array}$} \\
\hline $\begin{array}{l}\text { Received Desmber } \\
2018\end{array}$ & \\
\hline Received in & \\
\hline revised form & \\
\hline Desember 2018 & \\
\hline Accepted Januari & \\
\hline 2019 & \\
\hline Available online & \\
\hline January 2019 & \\
\hline \multirow[t]{2}{*}{$\begin{array}{l}\text { Kata kunci: } \\
\text { Farmasi, Pelayanan } \\
\text { Farmasi, Permenkes } \\
\text { No. } 35 \text { tahun } 2014 .\end{array}$} & \\
\hline & \\
\hline \multirow[b]{2}{*}{$\begin{array}{l}\text { Keywords: } \\
\text { Pharmacy, Pharmacy } \\
\text { Service, Permenkes } \\
\text { No. } 35 \text { of } 2014\end{array}$} & abstract \\
\hline & $\begin{array}{l}\text { The government issued Minister of Health Regulation No. } 35 \text { of } 2014 \text { concerning } \\
\text { Pharmacy Standards at the Pharmacy to serve as guidelines for pharmacist practice in } \\
\text { carrying out professional duties to protect the community from Services. The purpose } \\
\text { of this study is to find out the evaluation of the standard implementation of } \\
\text { pharmaceutical services at the Tegal City Regional Pharmacy in } 2018 \text {. This research is } \\
\text { a descriptive quantitative analysis research. The source of the primary research data } \\
\text { and tools in this study is a questionnaire sheet. Research Results from the Management } \\
\text { Aspects of Pharmaceutical Preparations and Pharmacy Health Supplies in the City of } \\
\text { Tegal Has carried out the management of Pharmaceutical Preparations with Good } \\
\text { Category, as well as the Aspects of Pharmacy Resource Management in terms of the } \\
\text { presence of Pharmacists and Medical Personnel, but there is less to the presence or } \\
\text { absence of pharmacists at the Pharmacy. The aspects of facilities and infrastructure in } \\
\text { providing a closed space for counseling can only be said to be sufficient. Aspects of } \\
\text { Clinical Pharmacy Services are said to be lacking for monitoring drug therapy, } \\
\text { monitoring drug side effects, and home care1. From the aspect of evaluation of service } \\
\text { quality, recording medication records is said to be lacking. Whereas the quality of } \\
\text { clinical services is also said to be good for attention to allergies, pharmaceutical } \\
\text { examination of drugs, and examination of drug availability, but lack of attention to dual }\end{array}$ \\
\hline
\end{tabular}


Sari Prabandari, Anggy Rima Putri, Vol 8 (1) 2019 pp 65-71

\begin{tabular}{|l|l|l|}
\hline & $\begin{array}{l}\text { medications and contraindications. As well as in the dimension of waiting time, drug } \\
\text { service is said to be sufficient. }\end{array}$ \\
(2)2019PoliteknikHarapanBersamaTegal
\end{tabular}

Alamat korespondensi:

Prodi DIII Farmasi Politeknik Harapan Bersama Tegal

Gedung A Lt.3. Kampus 1

Jl. Mataram No. 09 Kota Tegal, Kodepos 52122

Telp. (0283) 352000

p-ISSN: 2089-5313

E-mail: parapemikir_poltek@yahoo.com

e-ISSN: 2549-5062 


\section{Dinar Anggia Zen, Oktariani Pramiastuti, Vol 8 (1) 2019 pp 1-4}

\section{Pendahuluan}

Pemerintah menerbitkan Permenkes No. 35 tahun 2014 tentang Standar Pelayanan Kefarmasian di Apotek untuk dijadikan sebagai pedoman praktik apoteker dalam menjalankan tugas profesi guna melindungi masyarakat dari Pelayanan, dan Evaluasi Mutu Pelayanan ${ }^{1}$. Standar Pelayanan Kefarmasian di Apotek berdasarkan permenkes meliputi standar pengelolaan Sediaan Farmasi, Alat Kesehatan, dan Bahan Medis Habis Pakai, serta standar pelayanan farmasi klinik. Penyelenggaraan Standar Pelayanan Kefarmasian di Apotek harus didukung oleh ketersediaan sumber daya kefarmasian yang berorientasi kepada keselamatan pasien. Sumber daya kefarmasian sebagaimana dimaksud meliputi sumber daya manusia dan sarana prasarana. Untuk menjamin mutu Pelayanan Kefarmasian di Apotek, harus dilakukan evaluasi mutu Pelayananan Kefarmasian sehingga seluruh aspek pelaksanaan pelayanan kefarmasian dapat berjalan sesuai dengan tujuan pelayanan kefarmasian di apotek yaitu meningkatkan mutu pelayanan kefarmasian, menjamin kepastian hukum bagi tenaga kefarmasian, melindungi pasien dan masyarakat dari penggunaan Obat yang tidak rasional dalam rangka keselamatan pasien (patient safety) ${ }^{1}$. Tujuan dari penelitian ini yaitu mengetahui evaluasi pelaksanaan standar pelayanan kefarmasian di Apotek Wilayah Kota Tegal tahun 2018.

Beberapa Penelitian mengenai standar pelayanan kefarmasian sesuai Permenkes No. 35 tahun 2014 telah dilakukan sebelumnya. Namun hasil penelitian di beberapa kota menunjukkan bahwa pelayanan kefarmasian yang dilakukan di apotek masih dikategorikan kurang memenuhi standar yang telah ditentukan. Penelitian sebelumnya oleh Dari hasil penelitian bahwa presentase kehadiran apoteker di apotek di kota Padang adalah sebesar 58,67\% dan Pelayanan Kefarmasian di apotek kota padang masih dikategorikan kurang bila dilihat dari persentase ratarata $54,69 \%$ pada pemeriksaan resep ${ }^{2}$.

\section{Metodologi Penelitian}

Penelitian ini merupakan penelitian deskriptif analisis kuantitatif. Populasi penelitian sejumlah 76 apotek dan sampel sejumlah 43 apotek sesuai dengan kriteria inklusi dan eksklusi. Tekhnik sampling penelitian yaitu random sampling.

Variabel penelitian yaitu pelayanan kefarmasian yang dilihat dari empat aspek yaitu : Pengelolaan sediaan farmasi, alat kesehatan, bahan medis habis pakai, Pelayanan kefarmasian pada aspek farmasi klinik, Pelayanan kefarmasian pada aspek sumber daya, dan Evaluasi mutu pelayanan.

Sumber data yang digunakan dalam penelitian ini adalah sumber data primer yang diperoleh melalui kuisoner dengan kerangka dan garis besar pokokpokok yang dirumuskan kepada responden
(Berdasarkan Kepmenkes RI No. 35 Tahun 2014) tentang Standar Pelayanan Kefarmasian di Apotek. ${ }^{1}$

Secara umum penelitian ini dilakukan dalam tiga tahap. Tahap pertama yaitu persiapan dimana pada tahap ini melakukan persiapan dalam pengambilan data, tahap kedua yaitu penyebaran kuisoner kepada apotek diwilayah kota tegal. Dan yang terakhir adalah analisis data dengan melakukan analisa data yang berasal dari skor kuisoner yang telah disebar, menghitung jumlah rataan dan presentase data yang dapat dinilai berdasarkan tabel standard pelayanan kefarmasian ${ }^{1}$

\begin{tabular}{c|c}
\hline Skor $(\%)$ & Nilai \\
\hline $81-100$ & Baik \\
$61-80$ & Cukup \\
$20-60$ & Kurang \\
\hline
\end{tabular}

\section{Hasil dan Pembahasan}

Karakteristik Apotek di Kota Tegal

Karakteristik apotek merupakan suatu gambaran untuk menunjukan keadaan Apotik. Data Karakteristik dapat dilihat pada tabel.1.

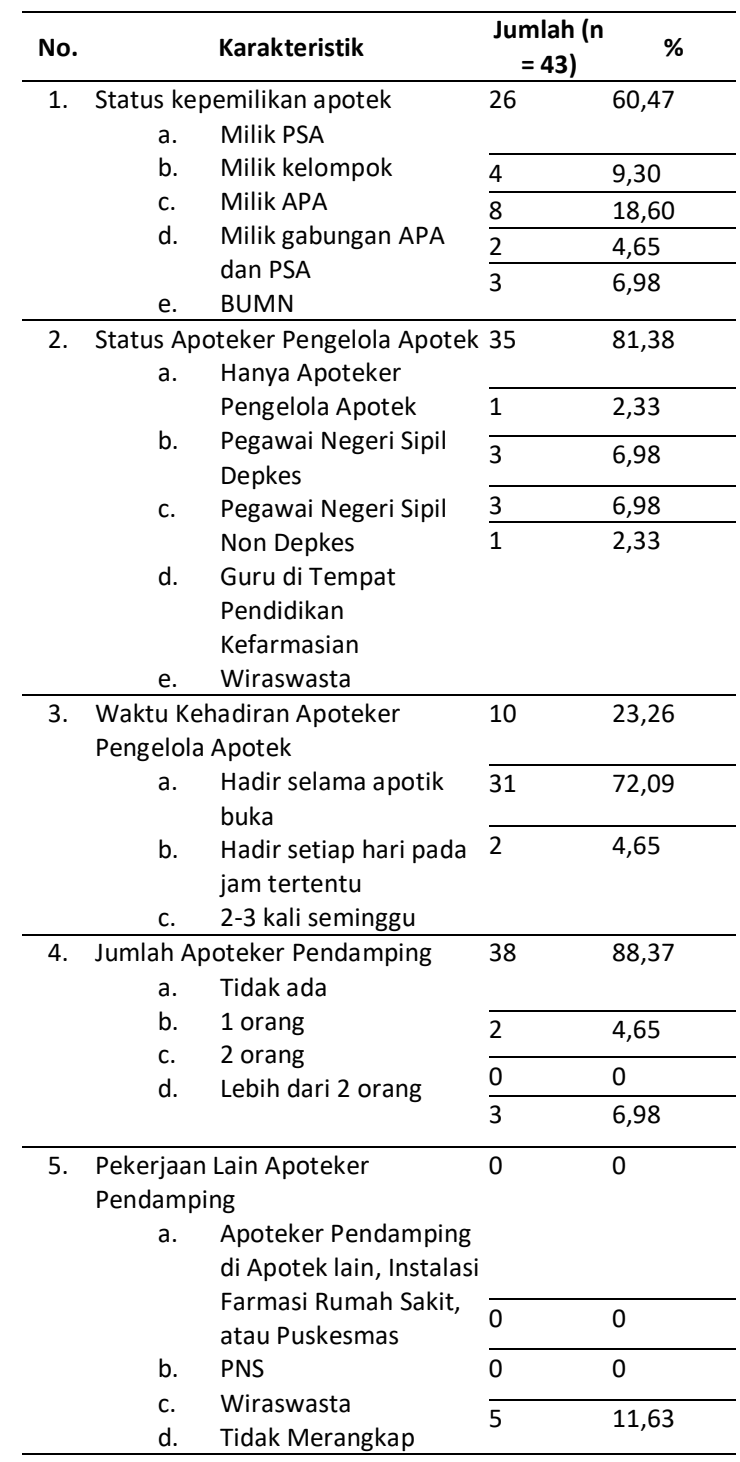




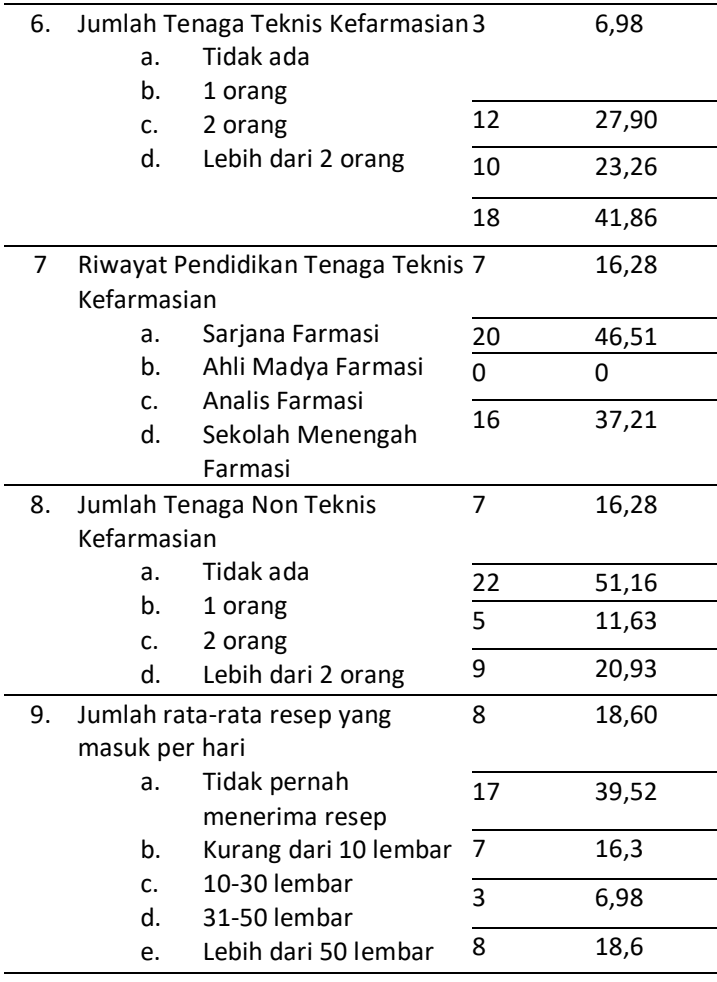

Menurut peraturan perundang-undangan, apotek harus dikelola oleh seorang apoteker. Apoteker merupakan satu-satunya subyek yang ditugaskan untuk mengelola apotek sehingga diberikan otoritas untuk kepentingan tersebut. Pengelolaan sumber daya manusia di apotek dapat dilihat dari kehadiran apoteker di apotek dan keikutsertaan dalam seminar dan pelatihan. Grafik kehadiran apoteker di Kota Tegal dapat dilihat dalam Gambar 1.

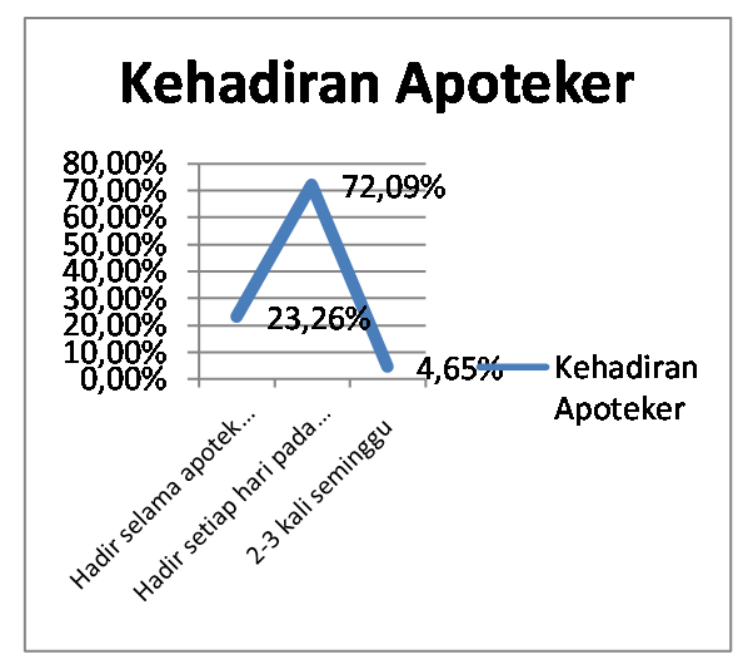

Pengelolaan Sediaan Farmasi dan Perbekalan Kesehatan
Tabel 2. Gambaran Pengelolaan Sediaan Farmasi dan Perbekalan Kesehatan di Apotek Kota Tegal

\begin{tabular}{|c|c|c|c|c|c|c|}
\hline & Pengelolaan & Jumla & $(n=43)$ & & & KET \\
\hline No. & $\begin{array}{c}\text { Dan } \\
\text { Perbekalan } \\
\text { Kesehatan }\end{array}$ & Ya & Tidak & Ya & Tidak & \\
\hline 1. & $\begin{array}{l}\text { Melakukan } \\
\text { perencanaan } \\
\text { pembelian }\end{array}$ & 42 & 1 & 97.67 & 2,32 & BAIK \\
\hline 2. & $\begin{array}{l}\text { Melakukan } \\
\text { pengadaan } \\
\text { melalui jalur } \\
\text { resmi }\end{array}$ & 43 & 0 & 100 & 0 & BAIK \\
\hline 3. & $\begin{array}{l}\text { Obat atau } \\
\text { bahan obat } \\
\text { disimpan dalam } \\
\text { wadah asli dari } \\
\text { pabrik, kecuali } \\
\text { ada } \\
\text { pengecualian } \\
\text { atau keadaan } \\
\text { darurat }\end{array}$ & 40 & 3 & 93,02 & 6,97 & BAIK \\
\hline 4. & $\begin{array}{l}\text { Penyimpanan } \\
\text { sediaan farmasi } \\
\text { dan perbekalan } \\
\text { kesehatan pada } \\
\text { tempat yang } \\
\text { sesuai dan layak }\end{array}$ & 40 & 3 & 93,02 & 6,97 & BAIK \\
\hline 5. & $\begin{array}{l}\text { Penyimpanan } \\
\text { obat sesuai FIFO }\end{array}$ & 43 & 0 & 100 & 0 & BAIK \\
\hline 6. & $\begin{array}{l}\text { Penyimpanan } \\
\text { obat sesuai } \\
\text { FEFO }\end{array}$ & 43 & 0 & 100 & 0 & BAIK \\
\hline 7. & $\begin{array}{l}\text { Penyimpanan } \\
\text { narkotika sesuai } \\
\text { ketentuan }\end{array}$ & 43 & 0 & 100 & 0 & BAIK \\
\hline 8. & $\begin{array}{l}\text { Penyimpanan } \\
\text { psikotropika } \\
\text { sesuai } \\
\text { ketentuan }\end{array}$ & 43 & 0 & 100 & 0 & BAIK \\
\hline
\end{tabular}

Berdasarkan data pada tabel 2. tersebut diperoleh hasil bahwa kegiatan pengelolaan sediaan farmasi dan perbekalan kesehatan secara umum telah dilakukan dengan baik oleh apotek di Kota Tegal. Data menunjukkan bahwa kegiatan perencanaan, pengadaan obat melalui jalur resmi, penyimpanan obat atau bahan obat di dalam wadah asli, dan penyimpanan sediaan farmasi dan 
perbekalan kesehatan di tempat yang layak. Apotek yang tidak melakukan perencanaan hanya $2,32 \%$ hal tersebut dikarenakan pembelian secara terpusat (apotik jaringan).

Pengelolaan Sumber Daya Apotek

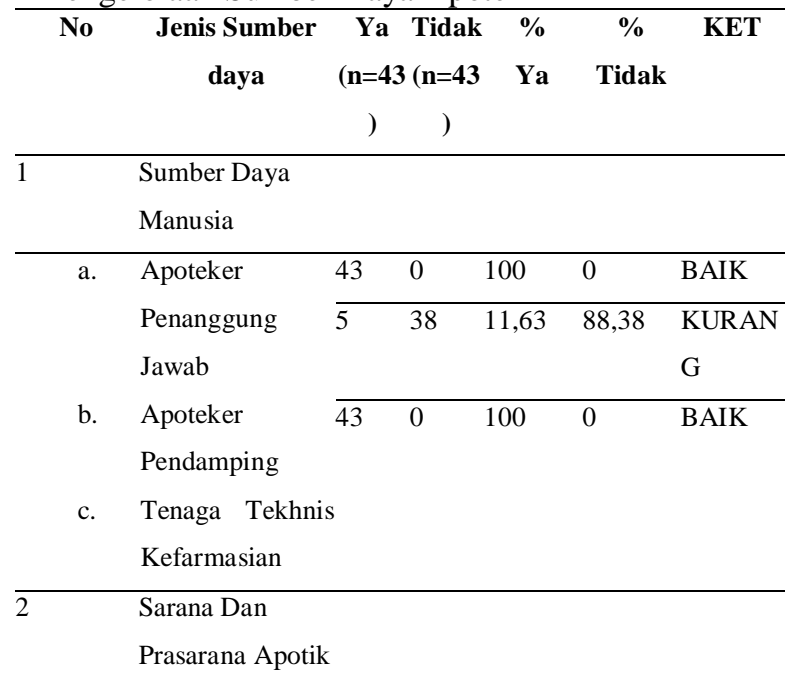

\begin{tabular}{|c|c|c|c|c|c|}
\hline $\begin{array}{l}\text { Di halaman } \\
\text { terdapat papan } \\
\text { petunjuk apotek }\end{array}$ & 43 & 0 & 100 & 0 & BAIK \\
\hline $\begin{array}{l}\text { Pelayanan } \\
\text { produk } \\
\text { kefarmasian } \\
\text { diberikan pada } \\
\text { tempat yang } \\
\text { terpisah dari } \\
\text { aktivitas } \\
\text { pelayanan dan } \\
\text { penjualan produk } \\
\text { lainnya }\end{array}$ & 43 & 0 & 100 & 0 & BAIK \\
\hline $\begin{array}{ll}\text { Terdapat ruang } & 4 \\
\text { tunggu yang } & \\
\text { nyaman } & \end{array}$ & 43 & 0 & 100 & 0 & BAIK \\
\hline $\begin{array}{l}\text { Terdapat tempat } 3 \\
\text { untuk mendisplai } \\
\text { informasi obat }\end{array}$ & & 6 & 86,05 & 13,95 & BAIK \\
\hline $\begin{array}{l}\text { Terdapat ruangan 2 } \\
\text { tertutup untuk } \\
\text { pelayanan } \\
\text { konseling }\end{array}$ & & 15 & 65,12 & 34,88 & CUKUP \\
\hline $\begin{array}{l}\text { Terdapat ruang } \\
\text { penyimpanan, } \\
\text { peracikan, dan } \\
\text { tempat } \\
\text { penyerahan obat }\end{array}$ & 43 & 0 & 100 & 0 & BAIK \\
\hline $\begin{array}{l}\text { Terdapat tempat } \\
\text { pencucian alat }\end{array}$ & 43 & 0 & 100 & 0 & BAIK \\
\hline $\begin{array}{l}\text { Di halaman } \\
\text { terdapat papan } \\
\text { petunjuk apotek }\end{array}$ & 43 & 0 & 100 & 0 & BAIK \\
\hline
\end{tabular}

Dari data tersebut dapat dilihat bahwa untuk pengelolaan sumber daya Apotek dilihat dari segi SDM, hampir dipastikan seluruh apotek yaitu presentase sebesar $100 \%$ di Kota Tegal memiliki Apoteker, hal ini memang sudah semestinya karena syarat dari pendirian sebuah Apotek memang harus memiliki seorang Apoteker yang nantinya sebagai penanggung jawab dari berdirinya sebuah apotek, dan juga memiliki seorang Asisten Apoteker hal tersebut sesuai dengan standard Pelayanan Kefarmasian Apotek Menurut Permenkes No 35. Tahun 2014.

Dalam hal sarana dan prasarana telah terlaksana dengan baik. Dari 43 responden, seluruh responden $(100 \%)$ telah melakukan pemasangan papan petunjuk apotek di halaman, memiliki ruang penyimpanan, tempat peracikan, tempat penyerahan obat, tempat pencucian alat dan ruang tunggu yang nyaman.

Pelayanan Farmasi Klinis

Beberapa apotek di Kota Tegal telah melakukan pelayanan farmasi klinis diantaranya telah melakukan pelayanan pengkajian resep sebesar $95,34 \%$, dispensing obat sebesar 97,67\%, konseling obat di apotek 88,37\%. Akan tetapi, beberapa bagian masih ada apotek yang tidak melakukan

\begin{tabular}{lccccc}
\hline \multirow{2}{*}{$\begin{array}{c}\text { Pengelolaan Sediaan } \\
\text { Farmasi Dan }\end{array}$} & \multicolumn{2}{c}{ Jumlah $(\mathbf{n}=$} & \multicolumn{2}{c}{$\%$} & KET \\
\cline { 2 - 6 } Perbekalan Kesehatan & Ya & Tidak & Ya & Tidak & \\
\hline Pengkajian Resep & 41 & 2 & 95,34 & 4,65 & BAIK \\
\hline Dispensing Obat & 42 & 1 & 97,67 & 2,32 & BAIK \\
\hline Konseling & 38 & 5 & 88,37 & 11,62 & BAIK \\
\hline Home care & 4 & 39 & 9,32 & 90,69 & KURANG \\
\hline Pemantauan terapi obat & 8 & 35 & 18,60 & 81,39 & KURANG \\
\hline Monitoring Efek Samping & 6 & 37 & 13,95 & 86,04 & KURANG \\
Obat & & & & & \\
\hline
\end{tabular}

kegiatan seperti pemberian konseling berkelanjutan, meskipun jumlahnya tidak terlampau besar. Hal tersebut disebabkan karena adanya keterbatasan sumber daya manusia.

Evaluasi Mutu Pelayanan Di Apotek

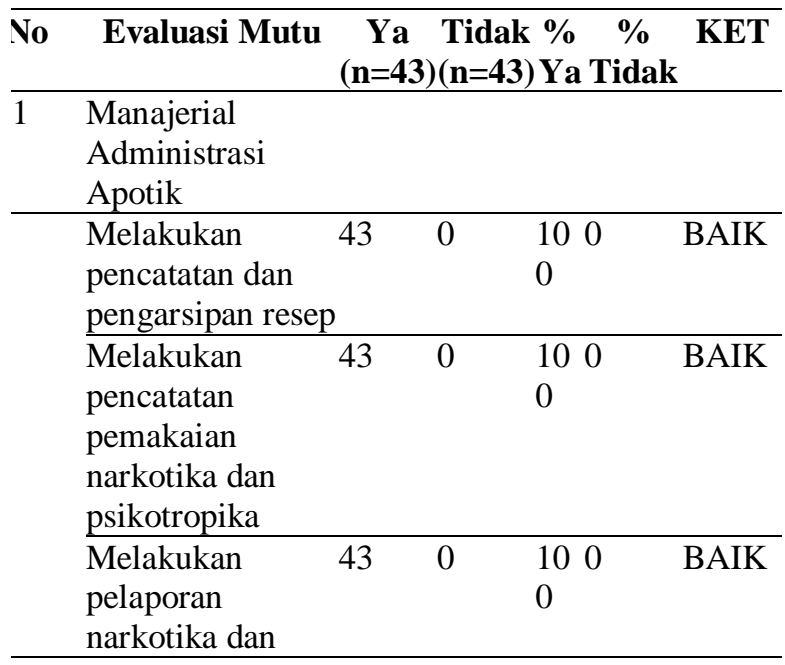




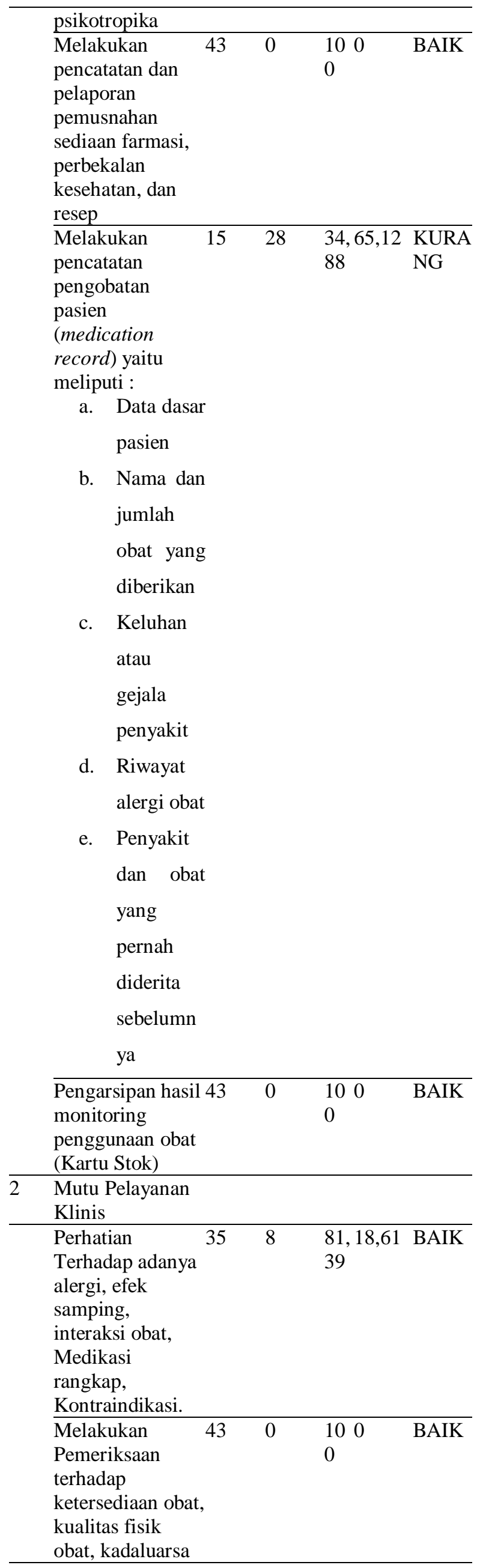

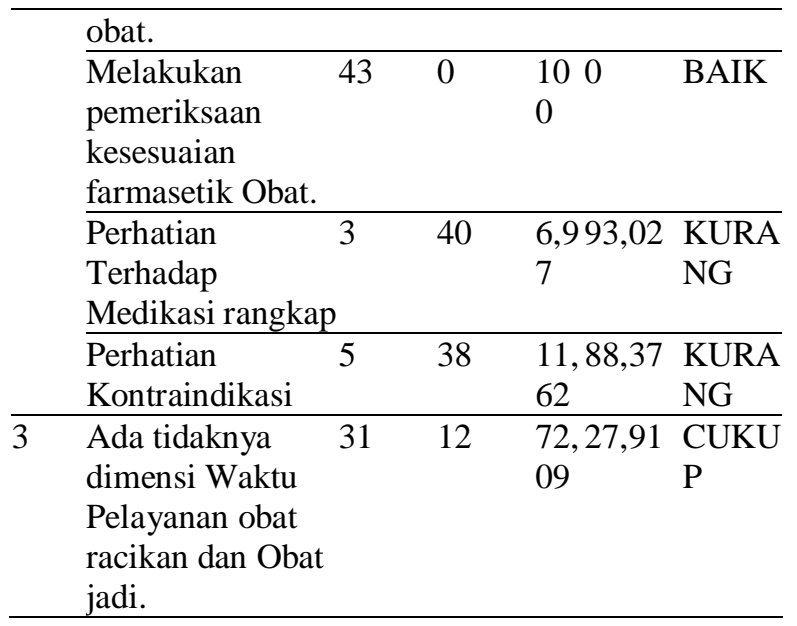

Berdasarkan hasil penelitian diketahui bahwa kegiatan administrasi yaitu pencatatan dan pengarsipan resep telah dilakukan oleh $100 \%$ apotek yang menerima resep yaitu sebanyak 43 apotek. Pencatatan dan pengarsipan resep perlu dilakukan untuk memudahkan pencarian ketika pasien datang lagi dengan menebus resep yang sama. Selain itu juga untuk memudahkan ketika akan melakukan pelaporan pemusnahan resep.

\section{KESIMPULAN}

Dari Aspek Pengelolaan Sediaan Farmasi Dan Perbekalan Kesehatan Apotek Di Kota Tegal Telah melakukan pengelolaan Sediaan Farmasi dengan Kategori Baik Berdasarkan Standard Permenkes No. 35 Tahun 2014.

Dari Aspek Pengelolaan Sumber Daya Apotek, Apotek Di Kota Tegal dari segi Ada tidaknya Apoteker dan Tenaga Kefarrmasian dikatakan Baik karena telah memilikinya, namun kurang untuk ada tidaknya apoteker pendamping di Apotek. Sedangkan untuk aspek sarana dan prasarana bisa dikatakan baik untuk penyediaan fasilitas, namun pada penyediaan ruang tertutup konseling hanya bisa dikatakan cukup.

Dari Aspek Pelayanan Farmasi Klinis bisa dikatakan baik dalam hal pengkajian resep, dispensing obat, dan konseling, namun dikatakan kurang untuk hal pemantauan terapi obat, monitoring efek samping obat, dan home care.

Dari Aspek Evaluasi Mutu pelayanan Apotek di Kota Tegal dalam Manajerial Administrasi Apotek dikatakan Baik, namun untuk pencatatan medication record dikatakan kurang. Sedangkan Mutu pelayanan Klinis juga Dikatakan Baik pada perhatian terhadap alergi, pemeriksaan farmasetik obat, dan pemeriksaan ketersediaan obat namun kurang pada bagian perhatian pada medikasi rangkap dan kontraindikasi. Serta pada bagian dimensi waktu tunggu pelayanan obat dikatakan cukup

\section{UCAPAN TERIMAKASIH}

Peneliti mengucapkan terimakasih kepada : Dirjen Dikti, Bagian P3M Politekhnik Harapan Bersama 
Kota Tegal, Dinas Kesehatan Kota Tegal, Ikatan Apoteker Indonesia Kota Tegal

\section{REFERENSI}

[1] Depkes RI. 2014. Keputusan Menteri Kesehatan Republik Indonesia Nomor 35 Tahun 2014 tentang Standar Pelayanan Kefarmasian di Apotek, Departemen Kesehatan Republik Indonesia, Jakarta.

[2] Dominica Dwi, Dedi P.P, Yulihasri, 2016, Pengaruh Kehadiran Apoteker Terhadap Pelayanan Kefarmasian Di Apotek Di Kota Padang, Jurnal Sains Farmasi \& Klinis, Ikatan Apoteker Indonesia, Sumatera Barat.99-107

[3] Dirjen Binfar. 2008. Petunjuk Teknis Pelaksanaan Standar Pelayanan Kefarmasian di Apotek, Direktorat Jenderal Bina Kefarmasian dan Alat Kesehatan, Jakarta.

[4] Depkes RI. 2006. Keputusan Menteri Kesehatan Republik Indonesia Nomor

[5] 1027/MENKES/SK/IX/2004 tentang Standar Pelayanan Kefarmasian Di

[6] Apotek, Departemen Kesehatan Republik Indonesia, Jakarta.
[7] Fauziyah, P.N. dan Satibi. 2012. Evaluasi Implementasi Standara Pelayanan Kefarmasian oleh Apoteker di Apotek Kabupaten Bantul, Jurnal Manajemen dan Pelayanan Farmasi.

[8] Ginting, A.B.R. 2009 Penerapan Standar Pelayanan Kefarmasian di Apotek di

[9] Kota Medan, Skripsi, Fakultas Farmasi Universitas Sumatra Utara Medan.

[10] Imas N, Sri Saptuti W, 2016, Faktor Pelayanan Kefarmasian Dalam Peningkatan Kepuasan Pasien Di Pelayanan Kesehatan, Indonesia Journal On Medical Science, Prodi Farmasi, Poltekkes Bhakti Mulia.

[11] Inayah A， 2017， Evaluasi Standard Pelayanan Kefarmasian Di Apotek Kecamatan Adiwerna Kabupaten Tegal, Politekhnik Harapan Bersama, 2017.

[12] Kurniawaty, R.. 2013. Evaluasi Penerapan Standar Pelayanan Kefarmasian di Apotek Kota Tasikmalaya, Skripsi, Jurusan Farmasi, Universitas Jenderal Soedirman, Purwokerto 